\title{
PRAGMATIC MARKERS IN HUNGARIAN: SOME INTRODUCTORY REMARKS
}

\author{
HANS-MARTIN GÄRTNER-BEÁTA GYURIS \\ Research Institute for Linguistics \\ Hungarian Academy of Sciences \\ Benczúr u. 33. \\ H-1068 Budapest \\ Hungary \\ \{gaertner; gyuris\}@nytud.hu
}

\begin{abstract}
The purpose of these introductory remarks is to complement the following case studies by Ferenc Kiefer on majd 'later (on), sooner or later', Attila Péteri on hadd 'let', and Ildikó Vaskó on persze 'of course'. What we will do is sketch a number of what we consider promising theoretical developments that have a bearing on the issues raised in these studies. In a section addressing issues of form (section 2), we discuss "cartographic" approaches to adverb(ial) hierarchies and the clausal "left periphery", as well as pragmatic markers within clause types. In a section focusing on issues of interpretation (section 3), we deal with pragmatic markers from the perspective of "projective meaning" and "conversational moves".
\end{abstract}

Keywords: adverbs, adverbials, left periphery, clause types, speech acts, projective meaning, conversational moves

Curiouser and curiouser! cried Alice

\section{Introduction}

While work on this volume began within the framework of a GermanHungarian cooperation on "modal particles", ${ }_{1}^{1}$ we soon realized that, as far as Hungarian is concerned, we had to widen our views for at least the

${ }^{1}$ For input and stimulating discussion, we wish to thank the presenters at the meetings on "Modal particles and sentence types. A contrastive view from German and Hungarian", Katrin Axel, Donka Farkas, Magdalena Kaufmann, Stefan Kaufmann, Ferenc Kiefer, Jörg Meibauer, Attila Péteri, Ildikó Vaskó, and Malte Zimmermann, as well as further participants Regine Eckardt, Katalin É. Kiss, 
following two reasons. First, whereas German scholars recently had occasion to celebrate 40 years of "particle research" (cf. Harden-Hentschel 2010) - taking the seminal study by Weydt (1969) as starting point for a fairly consistent voluminous body of research-, works on any comparable aspects of Hungarian are few and far between (for some overview, see Gyuris 2008). Secondly, as repeatedly pointed out by others on similar occasions, choice of terminology is a delicate matter in describing and delimiting the intended area of research at the grammar-pragmatics interface. It is the advantage of employing the term "pragmatic marker" (AijmerSimon-Vandenbergen 2009; Fraser 1990; 1996) that it least prejudges the issues of form and interpretation that adequate formally explicit theories about are only beginning to emerge. ${ }^{2}$

The purpose of these introductory remarks is to complement the following case studies by Ferenc Kiefer on majd 'later (on), sooner or

Eric McCready, and Markus Steinbach, among others. Some of our work has also been presented at the 3rd Workshop on Contrast (Berlin, 4 May 2007), ICSH 8 (New York, 24 May 2007), the 7th Conference on New Methods of Describing Present-Day Hungarian (Szeged, 25 October 2007), the 18th International Congress of Linguists (Seoul, 24 July 2008), Sinn und Bedeutung 13 (Stuttgart, 30 September 2008), the 10th Workshop on the Roots of Pragmasemantics (Szklarska Poręba, 15 March 2009), LAGB (Edinburgh, 7 September 2009), and SPSW 2 (Göttingen, 29 May 2010).

For financing the project meetings we are grateful to the German Science Foundation (DFG) (Grant Nr. GA692/3-1), the Hungarian Research Fund (OTKA) (Grant Nr. F 68139), and the Hungarian Academy of Sciences. Research by HansMartin Gärtner was additionally in part supported by the Bundesministerium für Bildung und Forschung (BMBF) (Grant Nr. 01UG0711).

2 There is a wealth of predominantly function-oriented overviews and (collections of) case studies such as the ones by Aijmer-Simon-Vandenbergen (2006; 2009); Blakemore (2004); Brinton (2010); Dér (2010); Fischer (2006); Foolen (1996); Fraser (1988; 1999); Lenk (1997); Romero-Trillo (2009); Schiffrin (2003) and Schourup (1999).

Zwicky (1985, sections 3-4) provides a lucid negative assessment of the prospects for arriving at a unified morphophonological and/or morphosyntactic category (or level) of "particles". This is in stark contrast with most of the rather unsatisfactory classificatory attempts based on unanalyzed mixtures of formfunction criteria (e.g., Hentschel-Weydt 2002; Sasse 1993). Much along the latter line, the Hungarian descriptive tradition has not yet been able to settle on any principled approach to the inventory of adverbs (határozószó), modifying words (módosítószó), modal words (modális szó), (modal/shading) particles ((modális/ árnyaló) partikula), lexeme-like relational words (lexémaszerü viszonyszó), etc. Thus, in what follows, our use of the term particle is a purely expository device. 
later' (henceforth referred to as K-m), Attila Péteri on hadd 'let' (P-h), and Ildikó Vaskó on persze 'of course' (V-p). What we will do is sketch a number of what we consider promising theoretical developments that have a bearing on the issues raised in these three studies. We begin by a section addressing issues of form (section $\mathbf{2}$ ) and finish with a section focusing on issues of interpretation (section $\mathbf{3}$ ).

\section{Form}

\subsection{Cartography}

As is well known, functional categories have played an important role in refining phrase structural analyses within generative syntax. Starting from recognition of the categories AUX/INFL and COMP - integrated into X-bar-theoretic format since Chomsky (1986) as (heads of) IP and CP, respectively - various proposals for "splitting" IP (e.g., Pollock 1989; Ouhalla 1991) and CP (e.g., Müller-Sternefeld 1993; Zwart 1993) have been made. These trends were further radicalized within the socalled "cartographic" approach to syntax (cf. Shlonsky 2010 for a recent overview). The seminal cartographic studies of adverb(ial) hierarchies by Cinque (1999; cf. Alexiadou 1997) and of the "fine structure of the left periphery" by Rizzi (1997) have resulted in heightened awareness for and intensified investigation into the kind of subtle distributional evidence that things like pragmatic markers can provide. We will therefore begin by asking how Hungarian pragmatic markers can be fit into these two pictures.

\subsubsection{Hierarchies of adverb(ial)s and functional projections}

As is equally well known, Cinque (1999) postulated some 30 or so functional categories to capture cross-linguistic ordering regularities among (types of) adverbials and related head-like categories (affixes, auxiliaries, etc.). As documented in É. Kiss (2009a), the results can (at least) in part be replicated for Hungarian. Thus, to mention just one example, among "low adverbials", i.e., adverbials close to the clausal predicate, the ones expressing frequency precede the ones expressing manner, as shown in (1) (É. Kiss 2009c, 22): ${ }^{3}$

${ }^{3}$ For familiar reasons to do with Hungarian clause structure, only preverbal orderings are considered. É. Kiss (2009b;c) also sketches an approach to postverbal 
(1) (a) János gyakran jól megoldotta a feladatot. John often well vm.solved the problem

'John often solved the problem well.'

(b) *János jól gyakran megoldotta a feladatot.

Likewise, among "high adverbials", i.e., adverbials close to the root node of the clause, evidential expressions strongly prefer to precede epistemic modal expressions, as shown in (2) (cf. É. Kiss 2009c, 23):

(2) (a) Szerintem valószínủleg JÁNOST választják meg. according.to.me probably John.acc elect.they vm 'In my opinion, they probably elect JoHn.'

(b) ? Valószínủleg szerintem JÁNOST választják meg.

Now, of the pragmatic markers more closely studied in this volume, majd, translatable as 'later (on)' or 'sooner or later', and persze, translatable as 'of course', have been considered adverb-like (see, e.g., K-m: section $\mathbf{1}$; Prószéky 1989, 232-7; Simonyi 1892, 352; Vaskó 2001, 275 for majd; Simonyi 1892, 369; V-p: section $\mathbf{3 . 1}$ for persze). ${ }^{4}$ In a preliminary investigation of ordering possibilities we could come up with the following "boundary conditions": Among the "high adverbials", majd has to stay below evaluative ones and persze below speech act adverbials. This is shown in (3) and (4), respectively.

adverb(ial) positions. Prosodic annotation of example sentences will be minimal throughout. However, where important, focus will be indicated by small capitals and penultimate fall-rise on polar interrogatives by $[\wedge]$ at the end. For extensive discussion of Hungarian prosody, see Varga (2002).

4 The adverbial nature of persze may, at first sight, be inferred from the existence of alternations involving the complementizer hogy 'that' like Persze eljön/Persze, hogy eljön 'Of course, he is coming'. Varieties of this kind of alternation have been taken as criterial for identifying the likes of "modal words" by, among others, H. Molnár (1959); Antal (1975); Fábricz (1985); Péter (1991), and Péteri (2002): Valószínúleg eljön/Valószínü (az), hogy eljön 'He is probably coming'/'It is probable that he is coming' (cf., e.g., Jackendoff 1972, chapter 3, for application of this diagnostic to the classification of adverbs). However, as further tests show, persze, hogy must be considered a fixed expression - originating from the Latin per se intelligitur ut (cf. V-p: section 2) - instead of a standard predicative adjective plus complementizer configuration: (nem) valószínü/*persze (az) hogy... 'it is (not) probable/*of course that...' 
(3) (a) Szerencsére majd Béla megtartja az előadást. luckily Béla vm.hold.3sg the lecture.acc 'Luckily, Béla will hold the lecture.'

(b) *Majd szerencsére Béla megtartja az előadást.

(4) (a) Komolyan, persze Béla megtartja az előadást. seriously Béla vm.hold.3sg the lecture.acc 'Seriously, Béla will of course hold the lecture.'

(b) *Persze komolyan Béla megtartja az előadást.

Among the "low adverbials", both majd and persze-parenthetical uses aside - have to stay above the ones relating to habitual aspect. This is shown in (5).

(5) (a) Béla majd/persze általában megtartja az előadást. Béla usually vm.hold.3sg the lecture.acc

'Béla will usually hold the lecture.'/'Béla of course usually holds the lecture.'

(b) *Béla általában majd/persze megtartja az előadást.

These results would be consistent with a "naive" approach that counts majd among the temporal and persze among the epistemic or evidential adverbials. However, things are more complicated. As the contrast in (6) shows, a semantically closely related bona fide temporal adverb like később 'later' can be focused while majd cannot.

(6) (a) János később/majd elutazik.

John later/majd vm.travel.3sg

'John will leave later.'

(b) János később/*majd utazik el.

'John will leave LATER.'

Non-focusability is one of the hallmarks of (certain) "sentence adverbials" (cf., e.g., É. Kiss 2009c, 36) and we will come back to its interpretive side in section 3.1. Here it can serve to set up another-even more intricate-mismatch, which shows up when one studies persze wrt a class of comparable epistemic adverbials expressing "certainty". Thus, as predicted for "sentence adverbials", kétségtelenül 'undoubtedly' - to take just one example - cannot be focused, and neither can persze. This is illustrated in (7). 
(7) (a) A macska kétségtelenül/persze megette a madárfiókát. the cat undoubtedly/persze vm.ate the nestling.acc 'The cat undoubtedly/of course ate the nestling.'

(b) *A macska kétségtelenül/persze ette meg a madárfiókát.

Egedi $(2009,120)$ shows that, along with other expressions of what she calls the "certainty-class", kétségtelenül can attract the main stress and trigger stress reduction on the material following it: ${ }^{5}$

(8) A macska KÉTségtelenül megette a madárfiókát.

However, although some "Hungarian pragmatic/modal particles (valóban/tényleg/csakugyan/igazán, all of them meaning 'indeed, really')" (Egedi 2009, 125) belong in this "certainty-class" and pattern with kétségtelenül, persze does not. This is shown in (9).

(9) *A macska PERsze megette a madárfiókát.

Now, while É. Kiss (2009b; c) and Egedi (2009) embraced Cinque's heuristics in the search for a detailed map of adverbial hierarchies in Hungarian - a full exploration of the (at least) 30! permutations is, of course, still outstanding - , they have been reluctant to postulate additional functional categories. Instead they have relied on adjunction of adverbials to independently established projections like PredP, FocP, and TopP. ${ }^{6}$ Finer ordering asymmetries, as the ones in (1) and (2), are left to a typebased semantics - yet to be fully fleshed out - of the kind envisaged by Ernst (2002; 2007). One exception, however, concerns the relative order of "higher adverbials" and topics. This affects the "fine structure of the left periphery", which we turn to next.

\subsubsection{The left periphery}

As is also well known, Rizzi (1997) assumed that, in essence, the cartographic map of split CP yields at least the following grid of functional projections:

(10) ForceP $>$ TopP $>$ FocP $>$ FinP

${ }^{5}$ Prószéky (1989) and Kiefer (2005) made similar observations.

${ }^{6}$ Evidence against adjunction building on the free interspersion of verbal head positions (cf. Shlonsky 2010, 421-2) does not seem to apply in Hungarian. 
Since the publication of this proposal, an enormous amount of work has gone into presenting refinements of and alternatives to (10). This is documented, for example, in the collections edited by Adger et al. (2004); Lohnstein-Trissler (2004); Rizzi (2004); Shaer et al. (2009) and BenincàMunaro (2011).

From the perspective of Hungarian syntax, especially TopP and FocP have been paid closer attention to, given that these - as already mentioned above - tend to be counted among the established ingredients of Hungarian clause structure (cf., e.g., É. Kiss 2002). ${ }^{7}$ In particular, the idea that TopP and FocP actually consist of more articulated "fields" of projections (cf., e.g., Benincà-Poletto 2004) chimes well with earlier approaches to Hungarian (cf., e.g., Brody 1990).

Now, sentence adverbials - to return to what we left open at the end of section $\mathbf{2 . 1}$ - have traditionally been taken as marking the boundary between "topic field" and "focus field", that boundary being "the rightmost position where a sentence adverbial can be inserted" (É. Kiss 2002, 12). Consequently, (DP-)constituents preceding sentence adverbials within the same "C-domain" count as topics. Since "[s]entence adverbials can precede or follow the topic" (ibid.), one might expect finer distinctions among sentence adverbials and topic types to reveal additional fine structure (cf. Benincà-Poletto 2004). Let us have a brief look at three cases that seem to weigh in favor of this intuition. ${ }^{8}$

First, epistemic and evaluative sentence adverbials have played an important role in locating a topic position in the "middle field" of German clause structure. Thus, Frey (2004) shows that aboutness topics have to precede such adverbials. This result applies to Hungarian too (cf. É. Kiss 2008, 288, fn. 2). (11) illustrates one of the crucial contrasts, based on cataphora (cf. Reinhart 1981).

(11) (a) Ha jó híreket kap, akkor János valószínüleg

if good news.acc receive.3sg then John probably

átmegy holnap a vizsgán.

vm.pass.3sg tomorrow the exam.on

"If he $\boldsymbol{i}_{\boldsymbol{i}}$ receives good news, $\mathrm{John}_{\boldsymbol{i}}$ will probably pass the exam tomorrow.'

(b) ??Ha jó híreket kap, akkor valószínűleg János átmegy holnap a vizsgán.

${ }^{7}$ Critical counterproposals are made, among others, by Surányi (2004) and Horvath (2010).

${ }^{8}$ Further examples may be forthcoming from work on the readings of indefinites related to their positions relative to adverbials in "all-new" or "thetic" sentences (cf. Maleczki 2001; Gécseg 2006; Gécseg-Kiefer 2009). 
On a (cataphoric) coreferential reading (of the null pronoun in the conditional protasis), János will be construed as aboutness topic. On this reading the DP János has to precede the epistemic adverb valószinúleg as in (11a).

Secondly, Lipták (2011; cf. Lipták 2001) argues in favor of a syntactic distinction between ordinary "non-contrastive" and "contrastive topics" in Hungarian. The latter are taken to be hosted by a functional projection, CTopP, while TopP is reserved for the former. Particularly interesting for us is a type of contrastive topics that is not marked intonationally but by immediately right-adjacent "contrastive particles" (Lipták 2011, 180). This adjacency condition is one of the properties that motivate treating these items as heads of CTopP, as shown in (12) (cf. Lipták 2011, 194).

$$
\begin{gathered}
{\left[\mathrm { CTopP } A \text { zöldséget } \left[\mathrm{CTop}^{\prime}\left[\mathrm{CTop}^{0} \text { pedig }\right]\right.\right.} \\
\text { the vegetable.acc }
\end{gathered} \begin{array}{cc}
\text { PredP eladjuk }]]] \\
\text { 'The vegetables, however, we sell.' }
\end{array}
$$

Among the many non-trivial consequences of this proposal, the one most directly affecting the fine structure of the left periphery is the interaction of "contrastive particles" with relative pronouns shown in (13) (Lipták 2011, 189).

(13) Mindenki az igazgatót kereste, aki viszont szabadságon volt. everyone the director.acc searched rel.who however holiday.on was 'Everyone was looking for the director, who, however, was on holiday.'

Given that on the intended reading, aki and viszont have to be adjacent, too, one seems to be forced to place the relative pronoun in Spec,CTopP. However, very simple distributional facts militate against this consequence. We have already mentioned that sentence adverbials may precede topics within the same clause. Likewise, in the unmarked case, TopP dominates CTopP, which means that ordinary topics may precede contrastive ones within the same clause, too (cf. Lipták 2011, 186). Yet, relative pronouns by and large occur strictly leftmost within relative clauses (cf., e.g., Kenesei 1994, 282). This is why they are taken to occupy ForceP within the extended left periphery in (10) (Rizzi 1997, 298, $325)$. One may thus be well advised to rethink the status of "contrastive particles". 9

${ }^{9}$ Lipták $(2011,189)$ notes that they alternatively function as (adversative) conjunctions. The adverbial-like behavior of their German counterparts has been observed by Pasch et al. (2003).

Acta Linguistica Hungarica 59, 2012 
Thirdly, two exceptions to the just mentioned "leftness condition" on relative operators in Hungarian require further refinements. Thus, as noted by Kenesei (1994, 302-3), in earlier stages of Hungarian, the standard complementizer hogy 'that' could precede a relative pronoun. The same holds for the modern Hungarian comparative complementizer mint 'as, than'. Now, one general intuition about hogy is that it takes a fully expandable clause as its complement. It therefore constitutes a prime candidate for filling the head of SubP, a projection that, e.g., Haegeman (2003, 335; 2012, 116; cf. Dalmi 2012, 119) —following work by, among others, Bhatt-Yoon (1992) - adds on top of (10) for the treatment of subordinate (or dependent) clauses. Applied to 16th century Hungarian relatives (cf. Kenesei 1994, 303) the result would look as in (14):

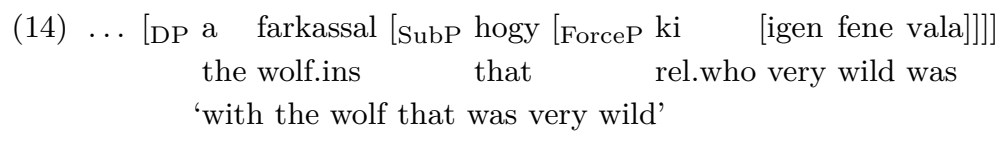

In addition, some relatives - along with conditionals and certain other types of subordinate clauses - allow a peculiar type of topicalization to the front of the relative operator (cf. Kenesei 1994, 304). Inspired by Bayer (2001), who analyzes related phenomena in Bavarian, we would like to suggest that certain clause types license a marked extension of ForceP by a topic projection we will call XTopP hosting "exceptional topics". One of the constraints on this projection in Hungarian derives from the interesting fact that XTopP is not an attachment site for sentence adverbials. This is shown by the contrast in (15). ${ }^{10}$

${ }^{10}$ A related alternative proposal is made by Kántor (2008). Contrary to what is claimed by É. Kiss $(2002,244)$, we are not convinced that XTopP is iterable. At least in (some variants of) spoken Hungarian, "X-topicalization" is able to intervene between items in $\mathrm{Sub}^{0}$ and the relative operator, as shown in (i), modeled on an example by Kenesei $(1994,302)$.

(i) Az ég sötétebb [SubP mint [XTopP Ervin képén

$$
\begin{aligned}
& \text { the sky darker than Ervin picture.his.sup } \\
& {[\text { ForceP amilyennek [mutatkozik]]]] }} \\
& \text { rel.what.dat look.3sg }
\end{aligned}
$$

'The sky is darker than it looks in Ervin's picture.' 
(15) (a) [XTopP A kirándulásra [ForceP aki [esetleg elmenne]]], the trip.onto rel.who possibly go.cond hozzon magával pénzt. bring.subj3.sg himself.with money.acc

'Whoever would possibly go on the trip, bring some money.'

(b) *[XTopP Esetleg [ForceP aki [elmenne a kirándulásra]]], hozzon magával pénzt.

The seemingly crucial role of ForceP in capturing properties of relative clauses motivates further reflection on its status within the left periphery. In fact, Egedi $(2009,113)$ and É. Kiss $(2009$ c, 35) find it convenient to follow Haegeman (2006) in replacing ForceP by a so-called "Speaker Deixis Phrase", SDP, located in a lower part of the left-peripheral hierarchy. More specifically, in order to capture the already mentioned variable insertability of sentence adverbials into the "topic field", they assume that these either adjoin to (one of the multiple) TopP(s) or, in the lowest position where no topic projects a hosting category, sentence adverbials occupy SDP. An example is provided in (16) (É. Kiss 2009c, 36):

(16) [TopP Valószínűleg [TopP János [SDP látszólag [PredP együttmüködött probably John seemingly cooperated

a rendőrséggel]]]]

the police.with

'Probably, John seemingly cooperated with the police.'

In order to better understand the consequences of this analysis, which in fact is incompatible with the treatment of relative clauses just sketched, we have to have a closer look at the full range of projections of Hungarian clause structure presupposed here (cf. É. Kiss 2009c, 26): ${ }^{11}$

(17) $(\mathrm{SubP}>)$ TopP $>\mathrm{SDP}[\approx$ ForceP $]>$ FocP $>$ NegP $>\mathrm{NNP}>$ PredP $>\mathrm{vP}>\ldots$

Postulating SDP for "low" sentence adverbials is in part motivated by a preference not to "adjoin them to the post-topic projection (i.e., to the maximal functional extension of the verb phrase: a PredP, FocP, or NegP) [...]. [...] intuitively sentence adverbials do not form part of the functionally extended verb phrase (the logical predicate); they are felt

${ }^{11}$ NNP, the "non-neutral phrase" involved in verb-vm-inversion will be replaced by FinP in section 2.2 (cf. É. Kiss 2009c, 25). 
to be external to it" (É. Kiss 2009c, 35). ${ }^{12}$ A "deeper" motivation for SDP is sought by Egedi (2009), citing Bellert (1977), who "observes that speaker-oriented adverbs such as evaluatives (fortunately), evidentials (evidently) and modals (possibly) have a rather restricted distribution: they are degraded in questions, imperatives and antecedents of conditionals, and they do not occur in the scope of negation" (Egedi 2009, 120). Also, "[s]ituating sentence adverbs in such a speaker-related functional projection of the $\mathrm{CP}$ domain that serves as an interface between the propositional content and its context seems reasonable. Sentence adverbs are attitude markers that provide additional information that is external to the proposition expressed by the core sentence. Speaker deixis may also host 'force' features (declarative, question, etc.) in Hungarian" (ibid., 113).

Now, although Haegeman (2006) is cited as the main source for the renaming of ForceP (into SDP) and its repositioning (below TopP), there is no discussion of Haegeman's actual approach to sentence adverbials. In particular, Haegeman's theoretical "showpiece", the treatment of conditional clauses, is sidestepped. According to this analysis, absence of "speaker-oriented adverbs" in the protasis of standard hypothetical indicative conditionals should be captured in terms of the absence of SDP. Consider (18) (ibid., 1652).

(18) If it (*probably) rains you may get wet.

That probably is banned here, follows from the assumption that this kind of conditional possesses a reduced ("truncated") structure lacking SDP (op.cit., 1663). (18) carries over to Hungarian directly, as shown in (19):

(19) Ha (*valószínüleg) esik, megázhatsz.

However, it is not difficult to see that the SDP-approach undergenerates. Thus, there are other sentence adverbials, like subject-oriented szándékosan 'willingly' ${ }^{13}$ that are perfectly fine in the same environment: ${ }^{14}$

12 É. Kiss $(2011,95)$ seems to have revised this assumption and allows adjunction of adverbials to TP, a reincarnation of PredP.

${ }^{13}$ Focus on egy hibás terméket in (20) is chosen in order to guarantee that szándékosan is in the "topic field".

${ }^{14}$ Haegeman (2012) - via intermediate steps taken in Haegeman (2007; 2010a;b) - has revised her account, and changed SDP back into ForceP and back 
(20) Ha Péter szándékosan egy hibás terméket ad el, if Peter willingly a faulty product.acc sell vm akkor nem fog kapni több megbízást. then not will get.inf more commission.acc

'If Peter willingly sells a faulty product, he will not get any more commissions.'

Without SDP, however, there is no attachment site for szándékosan in (20).

More generally, it is important to note that the SDP-approach subscribes to a perspective on the role of ForceP as primarily interpretationdriven - encoding semantico-pragmatic aspects of sentence mood, illocution, and indexicality. However, another, more form-oriented, perspective is possible. On the understanding of Cardinaletti-Roberts (2002, 158), Force is "a category that interfaces with discourse in matrix clauses and with a selecting predicate in embedded clauses." This seems to be roughly what Rizzi (1997) has in mind when placing relative operators in Spec,ForceP (see above). Illocutionary force is clearly not a category associated with standard (restrictive) relative clauses. Thus, to avoid terminological confusion, a relabeling of ForceP to TypeP (Grewendorf 2002,

into place, so that (10) plus SubP for subordinate clauses is by and large valid again. Most importantly, "truncation" is reconceptualized as a consequence of operator movement plus intervention. Thus, since the base position of epistemic modal adverbials is higher than the base position of the "irrealis operator" taken to move into the periphery of standard hypothetical indicative conditionals like (18)/(19) (Haegeman 2010b, 606), an intervention effect and hence ungrammaticality results. It follows that the projection hosting epistemic modal adverbials "cannot be activated" in such clauses (Haegeman 2012, 127). In addition, based on the adverbial hierarchy argued for by Cinque $(1999,106)$, the acceptability of (20) is correctly predicted: The base position of "volitionals" is lower than that of the "irrealis operator". However, it is left open exactly how Cinquean functional projections are related to the "left periphery" in (10).

Ürögdi (2012), who works in Haegeman's framework, finds Hungarian contrastive topics to be interveners in the sense just sketched. This is supposed to account for their being banned from, among other things, the complement of "factive(ly interpreted)" verbs like regret (ibid., 81). It is unclear to us, however, how this can be made consistent with the fact that bona fide contrastive topics like scope inverting quantifiers (cf. Büring 1997; Krifka 1998; Gyuris 2009b) are perfectly fine in the same environment, as shown in (i):

(i) A tanár sajnálja, hogy mindenki nem ment át a vizsgán. the teacher regret.3sg that everybody not went.3sg vm the exam.on 'The teacher regrets that not everybody passed the exam.' 
68; cf. Haegeman 2007, 295) is advisable on such an approach. Henceforth, this will be the label used. Our next section will be devoted to formal aspects of clause types, as they relate to pragmatic markers. Interpretive aspects will be addressed in section $\mathbf{3 . 2}$.

\subsection{Clause types and pragmatic markers}

The study of German "modal particles" or "Abtönungspartikeln" ("mitigators") - as is well known - is intricately linked to the study of clause types. Particularly great efforts have been made wrestling with two kinds of, fairly closely related, constraints: (i) selectivity and (ii) limited "embeddability" (cf. Thurmair 1989; Coniglio 2011, and references cited there). ${ }^{15}$ We have already seen a glimpse of the second constraint as it applies to sentence adverbials and conditional clauses in $(18) /(19)$ above. Another environment that has a clear impact on the occurrence of pragmatic markers like persze is provided by relative clauses. Note the difference between restrictives and non-restrictives in (21):

(21) (a) *Meg fogunk hívni mindenkit, aki persze előad

vm will.1pl invite.inf everyone.acc who vm.present.3sg

a konferencián.

the conference.on

'We will invite everyone who (*of course) presents at the conference.'

(b) Meg fogjuk hívni Máriát, aki persze előad

vm will.1pl invite.inf Maria.acc who vm.present.3sg

a konferencián.

the conference.on

'We will invite Maria, who of course presents at the conference.'

In line with discussion in the previous section, relativizers should be placed in Spec,TypeP. The full featural specification of the head Type ${ }_{[+\mathrm{REL}]}^{0}$ could then be responsible for distinguishing (21a) from (21b).

Now, interestingly, to the extent that majd is counted among the pragmatic markers (cf. K-m: section 4), the same environment shows that a completely uniform treatment of such markers is implausible. Majd is compatible with both restrictives and non-restrictives. ${ }^{16}$

${ }^{15}$ For a contrastive study of German and Hungarian, see Péteri (2002).

16 The same contrast between persze and majd arises in conditionals: persze is confined to what Haegeman (2003, 318; cf. Coniglio 2011, 4.2.5) calls "premise 
(22) (a) Meg fogunk hívni mindenkit, aki majd előad vm will.1pl invite.inf everyone.acc who vm.present.3sg

a konferencián. the conference.on

'We will invite everyone who later presents at the conference.'

(b) Meg fogjuk hívni Máriát, aki majd előad vm will.1pl invite.inf Maria.acc who vm.present.3sg

a konferencián.

the conference.on

'We will invite Maria, who later presents at the conference.'

More will have to be said about interpretive correlates of (non-)embeddability in section $\mathbf{3}$.

The first constraint, selectivity, has often been formulated in terms of (in)compatibilities between modal particles and sentence moods, i.e., declarative, interrogative, imperative, exclamative, etc. Thus, it is shown by Kiefer (K-m, section $\mathbf{1}$ ) that majd is freely combinable with all (major) sentence moods. Persze, on the other hand, seems at first sight to be confined to declaratives, much like what was noted by Egedi (2009) citing Bellert (1977) for "speaker-oriented" adverbials (see section 2.1.2 above). However, use in wh-interrogatives is possible, as shown by Vaskó (V-p, section $\mathbf{6})$. (23) is an example. ${ }^{17}$

(23) Mikor kell persze a telefonnak csörögnie?

when must the telephone.dat ring.inf.3sg

'When of all times does the phone ring, of course?'

Inserting persze into a wh-interrogative is one of the means of signaling that a "normal" question has been turned into a rhetorical one. We will come back to the interpretive side of this kind of speech act manipulation in section $\mathbf{3}$.

Sometimes the link between a pragmatic marker and a sentence mood or clause type is very close. Thus, Hungarian vajon (roughly ' $\mathrm{I}$ wonder') is restricted to interrogatives (cf. Kenesei 1992, 691; Kálmán

conditionals", while majd is also compatible with the standard hypothetical indicative conditionals discussed in section 2.1.2.

${ }^{17}$ It may appear at first sight that use of of course in imperatives is fine: A: What should I do? B: Take the job, of course! However, B's response is perhaps better analyzed as an elliptical declarative (You should take the job, of course). 
$2001,98),{ }^{18}$ bestowing on the questions expressed by them a certain "dubitative" or "reflective" flavor (see section 3.2). In fact, however, in order to reliably show that the restriction for vajon must be formulated wrt interrogative sentence mood and not wrt question acts, one has to come to grips with the notoriously difficult issue of distinguishing purely intonationally marked polar matrix interrogatives from declaratives. A crucial piece of evidence here are so-called "declarative questions" (Gunlogson 2003; 2008; Poschmann 2008), as these are often grouped with "questions" from a functional perspective (cf. Kálmán 2001, 100; and, for German, Horváth-Péteri 2005, 195, following Altmann 1993, 5.2). One tool for probing this is the scopal behavior of indefinites. Thus, as pointed out by Szabolcsi $(2002,220)$, items like valaki 'someone' do not scope under clausemate negation. This is illustrated by the declarative in (24), requiring an unambiguously specific reading of the indefinite:

(24) János nem hívott fel tegnap valakit.

John not called vm yesterday somebody.acc

'There is somebody John did not call yesterday.'

Intonationally marked polar interrogatives, on the other hand, allow both a specific and a non-specific reading of valaki, as shown in (25).

(25) János nem hívott fel tegnap valakit $[\wedge]$ ?

John not called vm yesterday somebody.acc

'There is somebody such that I ask you whether John did not call him/her.'

'Is there anybody who John did not call yesterday?'

"Declarative questions" have declarative surface syntax but share intonational features with interrogatives. In Hungarian, the latter consist in reduced versions of $[\Lambda]$ spread on all accent bearing items in the clause, except for the main verb when preceded by an item triggering stress reduction. Roughly, use of "declarative questions" implies seeking special "addressee ratification" (Gunlogson 2008, 129) for a speaker assumption. Now, concerning readings of indefinites, "declarative questions" pattern with declaratives, not interrogatives, as shown in (26). ${ }^{19}$

18 The chapter on "questions" in the latter is authored by Viktor Trón.

${ }^{19}$ English "declarative questions" are characteristically realized with an overall rising intonation. The test based on the specificity of indefinites in Hungarian is modeled on a corresponding test for English using polarity items (*There's anybody John did not call yesterday?) (cf., e.g., Gunlogson 2003, 21; König-Siemund 2007, 293). 
(26) ^ János $\wedge$ nem hívott fel $\wedge$ tegnap $\wedge$ valakit?

John not called vm yesterday somebody.acc

'There's someone John did not call yesterday?'

Likewise, crucially, vajon can be added to (25) but not to (24) or (26), strongly suggesting its sensitivity to interrogative sentence mood rather than question force. ${ }^{20,21}$

It has repeatedly been noted (cf., e.g., Altmann 1993, 1020) that the association between modal particles and clause types in German can become so close that what was a pragmatic marker turns into an obligatory

${ }^{20}$ Despite clear evidence that the distribution of vajon is comparable to that of (sentence) adverbials, Dalmi (2012, 119-20.; cf. Hill 2002 for Romanian oare) decides to place vajon in the specifier of ForceP of what looks like the left periphery in (10), supplemented with an outer CP corresponding to SubP in (17). The exact placement rules accompanying this decision are hard to establish. Clearly, however, ForceP turns into a freely iterable projection of the kind TopP is considered to be in the approaches by Rizzi (1997) and É. Kiss (2009c). Postverbal occurrences of vajon are derived by (remnant) VP-movement to an "outer" ForceP projection (Dalmi 2012, 120), which requires "evacuation" movements for word order adjustments of the kind introduced by Kayne (1998; see Błaszczak-Gärtner 2005 for some discussion). Again, the details are hard to establish since spelling out the consequences of deriving even the most elementary intransitive clauses is deemed unnecessary. Contrary to work by, e.g., Poletto and Pollock (2004) on the left periphery of interrogatives in Italian dialects, no independent evidence for advantages of resorting to remnant movement is provided. It seems to us, though, that an approach in terms of "standard" adverbial placement plus "Agree" in the spirit of Bayer-Obenauer (2011) — applied there to German "discourse particles" in "special" interrogatives - is more promising.

In line with our explorations of section 2.1.1, it is interesting to note that vajon seems to have to precede adverbs like szükségszerüen 'necessarily' and szándékosan 'willingly':

(i) (a) (Vajon) szükségszerűen (*vajon) elromlik az idő hétvégére? necessarily vm.deteriorate.3sg the weather weekend.onto 'Is the weather necessarily going to turn bad toward the weekend? (I wonder.)'

(b) (Vajon) szándékosan (*vajon) félrevezette az ügyfeleket? willingly vm.led.3sg the clients.acc

'Did he willingly mislead the clients? (I wonder.)'

${ }^{21}$ Quite misleadingly, in spite of the fact that the paper by Dalmi (2012) carries reference to vajon in its title, the main syntactic phenomena discussed there are completely independent of vajon, except for a case of pragmatic anomaly. The latter has been pointed out as one of the main effects in a handout (slides) from a talk by the present authors that Dalmi mentions but chooses not to properly cite. See section $\mathbf{3 . 2}$ below. 
clause type marker. Hungarian enclitic -e, marking polar interrogatives, may be of this kind. ${ }^{22}$ This would make it a prime candidate for heading TypeP in the slightly revised version of (10) and (17) given in (27).

$$
(\text { SubP }>) \text { TypeP }>\text { TopP }>\text { FocP }>\text { NegP }>\text { FinP }>\text { PredP }>\text { vP }>\ldots
$$

Such an analysis would seem to be in line with what was argued for by both Kenesei (1994, 5.2) and Szabolcsi (1994, 6.3). Of course, - $e$ surfaces as enclitic on the (finite) main verb, which makes licensing via something like an "Agree" operation necessary. Perhaps, more local licensing from Fin $^{0}$ is required in addition (cf. Dalmi 2012, 118). ${ }^{23}$

An element apparently in transition from (light) matrix verb via pragmatic marker to clausal typing device is the hortative marker hadd 'let' discussed by Péteri (P- $h$; cf. de Groot 2010, 4.3.6; Szücs 2010). ${ }^{24}$ The matrix verb hagy 'let' selects either an infinitival or a finite subjunctive complement, as shown in (28) (cf. den Dikken 2004, section 4).

(28) (a) Ádám hagyta a gyereket kimenni a kertbe.

Adam let.past.3sg the child.acc vm.go.inf the garden.into

'Adam let the child go out to the garden.'

(b) Ádám hagyta, hogy a gyerek kimenjen a kertbe.

Adam let.past.3sg that the child vm.go.subj.3sg the garden.into

'Adam let the child go out to the garden.'

${ }^{22}$ The historical evidence (Juhász 1991; Simoncsics 2003) is consistent with assuming that $-e$ arose from a tag-like structure based on either an interjection or a negative (copula) verb. The typing of interrogative clauses by particles and other devices is discussed in great detail by Cheng (1991). A comprehensive typological overview of (the placement of) "polar question particles" is provided by Dryer in chapter 92 of the World Atlas of Language Structures (WALS) (http://wals.info/chapter/92).

23 To make this consistent with the approach to (non-wh-)sluicing by van Craenenbroeck-Lipták (2008), one would have to base-generate -e (at least as high as) in $\mathrm{Fin}^{0}$, from where it attracts the finite verb. Sluicing could then involve PredP ellipsis (with accompanying bleeding of $\operatorname{Pred}^{0}$-to-Fin ${ }^{0}$ ).

${ }^{24}$ For the specific grammaticalization path, see Heine-Kuteva (2002, 190-2). Interestingly, this hortative marker seems to be an "areal feature" occurring likewise in Albanian (hájde), Bulgarian (xajde), Byelorussian (gájda), Czech (hajdy), Macedonian (ajde), Romanian (hajde), Russian ((g)aida), Serbo-Croatian (hàjde), Turco-Tatar/Turkish (ajda/haydi), and Ukrainian (hájda) (Tchizmarova 2005, 1144, fn.1). However, contrary to Hungarian hadd, at least Bulgarian xajde allows for 2nd-person singular uses (ibid., 1147). 
Hadd, which goes back to the 2nd-person singular definite subjunctive form of hagy, i.e., hagyd, is inserted in preverbal position into non-2ndperson instances of what are usually called "imperative" clauses.

(29) (a) Olvassa el János az újságot!

read.subj.3sg vm John the newspaper.acc

'May John read the newspaper!'

(b) Hadd olvassa el János az újságot!

read.subj.3sg vm John the newspaper.acc

'Let John read the newspaper!'

Note the inversion of finite verb and verbal modifier in (29), which distinguishes "imperatives" from finite subjunctive clauses such as the subordinate clause in $(28 \mathrm{~b})$.

Now, fully establishing the syntax of "hadd-clauses" (cf. P- $h$ : 3.2) is clearly beyond the scope of our remarks here, not the least because it presupposes establishing the syntax of "imperatives". ${ }^{25}$ A look at recent attempts at the latter (É. Kiss 2011; Varga 2012a;b) indicates that this is a difficult matter. There is substantial evidence (P- $h$; Szücs 2010), however, that hadd is part of the "focus field": First, accent can shift from the main verb onto hadd, a sign of integration into the (extended) "predicate complex". Secondly, topics and sentence adverbs, i.e., parts of the "topic field" (see section $\mathbf{2 . 1}$ above), precede hadd. And thirdly, quantifiers like mindenki 'everyone', standardly taken to attach immediately on top of the "focus field" (cf., e.g., É. Kiss 2002, 5.1), also precede hadd (Szücs 2010, 202).

For locating hadd within the "focus field", we are inclined to follow É. Kiss (2011, section 6) and postulate a mood-related projection that we will call "MP" directly on top of FocP. This is where we think hadd is placed. ${ }^{26}$

${ }^{25}$ In spite of the fact that hagy selects infinitival complements and that Hungarian possesses directive root infinitives (Bartos 2002), hadd is unable to combine with infinitives, as shown in (i).

(i) $\left({ }^{*}\right.$ Hadd $)$ le-ül-ni!

down-sit-inf

'(Let him/her) Sit down!'

${ }^{26}$ Cf. Turi $(2009,33,35)$, where MP is called "ImpP". The label "MP" is reserved there for a low projection encoding verbal mood (cf. also Varga 2012a, 269).

Acta Linguistica Hungarica 59, 2012 
(30) $($ SubP $>$ ) TypeP $>$ TopP $>$ MP $>$ FocP $>$ NegP $>$ FinP $>$ PredP $>$ vP $>\ldots$

Independent evidence for such an assumption comes from the fact that "standard" exhaustive focus must follow hadd, as shown in (31). ${ }^{27}$

(31) (a) Hadd csak PÉtert hívjuk meg! only Peter.acc invite.subj.1pl vm

'Let's invite only Peter!'

(b) *Csak PÉtert hadd hívjuk meg!

Concerning the position of the finite verb we are inclined to follow Varga $(2012 b, 10)$, who takes it to move from Pred ${ }^{0}$ to Fin $^{0}$. This idea is confirmed by postverbal positioning of the "low" adverbials discussed in section 2.1.1 above, as shown in (32). ${ }^{28}$

(32) (a) Péter hadd mossa gyakran/jól meg a kezét!

Peter wash.subj.3sg often/well vm the hand.his.acc

'Let Peter wash his hands often/well!'

(b) *Péter hadd gyakran/jól mossa meg a kezét!

Further details concerning the presence vs. absence of $\mathrm{V}^{0}$-to-Fin ${ }^{0}$-movement and the specification of MP and TypeP are highly intertwined with matters of interpretation to which we turn in section 3.2.

Péteri (P-h, section 3.1) makes the interesting observation that hadd can sometimes function in a way similar to a subordinating conjunction of purpose clauses. The exact details of this remain to be explored. It is clear though that the position of hadd is unchanged, given that it

27 The string in (31b) is fine if csak does not function as focusing particle but as a pragmatic marker (cf., e.g., Gyuris 2009a). PÉtert, then, is an instance of a (clause type specific) "exceptional" focus preceding MP (for further examples, see Szücs 2010, 203). This is positionally similar to "pre- $w h$-focus" pointed out by Varga $(1982,160)$ and studied in more detail by Brody-Szendrői (2010). There are a number of intricate additional constraints on filling FocP below hadd ( $\mathrm{P}-h$, 3.2; Szücs 2010).

${ }^{28}$ It is unclear to us why the same adverbs may optionally appear preverbally in "hadd-less" "imperatives":

(i) (a) Mosd gyakran/jól meg a kezed!

wash.subj.2sg often/well vm the hand.your.acc

'Wash your hands often/well!'

(b) Gyakran/Jól mosd meg a kezed! 
can be preceded by items of the "topic field" even in such environments. Also, there must be substantial further restrictions as a comparison with preposed bona fide purpose clauses shows:

(33) (a) Hogy sikerüljön a vizsga, alaposan fel kell készülni. that succeed.subj.3sg the exam thoroughly vm must prepare.inf 'In order to be successful on the exam, one has to prepare thoroughly.'

(b) *Hadd sikerüljön a vizsga, alaposan fel kell készülni.

\section{Interpretation}

Everyone familiar with the literature on pragmatic markers knows that the amount of work on their formal properties is vastly overshadowed by work on trying to capture aspects of their interpretation and use. ${ }^{29}$ Here we will limit ourselves to some recent attempts at integrating two such aspects into formal models of the "grammar-pragmatics interface". First, it is a commonplace that the contribution of pragmatic markers to the overall meaning of the expression they occur in/with is difficult to pin down. Even if, for example, the descriptive content of an item like majd can in principle be fixed to something like "at some time in the future", there seems to remain a surplus, often called "expressive meaning" (K-m: section 4), or - in a more recent attempt at a generalized approach (Simons et al. 2010) — "projective meaning". This is what we will very briefly look at in section 3.1. Also, it is notoriously difficult to separate the contribution of a pragmatic marker from the contribution made by the linguistic expression it is part of or associated with. In particular, as indicated by close affinities to specific clause types (cf. section 2.2 above), many pragmatic markers seem to be intricately linked to the contribution of sentence mood and its illocutionary impact on "conversational moves". Thus, for example, hadd occurs in a peculiar form of "non-addressee-oriented directives" $(\mathrm{P}-h)$. Our section 3.2 will be devoted to studying the latter kind of effects.

\subsection{Pragmatic markers and "projective meaning"}

We showed in section 2.1.1 that neither majd, (6b), nor persze, (7b), can be focused. That this is not a trivial consequence of morphophonological

${ }^{29}$ For references, see the overviews cited in footnote 2 .

Acta Linguistica Hungarica 59, 2012 
"stress-resistance" is clear from the fact that both can be used as response particles in one-word utterances (K-m, section 3; V-p, section 4). Nonfocusability makes perfect sense, though, if focus standardly marks the "main point(s)" of an utterance or "what is at issue", while pragmatic markers provide secondary, supplementary, or "procedural" information on how to integrate the utterance with (a discourse representation of) what was said (or assumed) before.

Potts (2005) presents a framework designed to separate (various kinds of) "non-at-issue" meaning from standard at-issue meaning by means of a type-driven mechanism. ${ }^{30}$ Along these lines, a very simple analysis of our markers could be devised as in (34).

(34) (a) Persze/Majd János lediplomázik.

John vm.graduate.3sg

'Of course,/Sooner or later, John will graduate.'

(b) $\langle\operatorname{Graduate}(j)$, OF.Course[Graduate $(j)]\rangle /$

$\langle\operatorname{Graduate}(j), \operatorname{sooner.or} . \operatorname{Later}[\operatorname{Graduate}(j)]\rangle$

The first component in (34b) indicates that uttering (34a) is first and foremost an assertion that John will graduate. The second component provides the additional information that the speaker takes this to be a matter of course or time. Multiple non-at-issue items will essentially be collected conjunctively in the second component. This correctly predicts that persze and majd can come in arbitrary order, as shown in (35). ${ }^{31}$

(35) (a) Persze majd János lediplomázik.

(b) Majd persze János lediplomázik.

(c) $\langle\operatorname{araduate}(j), \operatorname{of} \cdot \operatorname{course}[\operatorname{araduate}(j)] \&$ sooner.or.later $[\operatorname{araduate}(j)]\rangle$

Importantly, semantic operators like negation "target" (i.e., operate on) at-issue meaning, while they are bypassed by non-at-issue meaning. Since this is a feature well known from presupposition projection (cf., e.g., Karttunen 1973; Heim 1992), Simons et al. (2010) suggest that the entire class of phenomena should be subsumed under the term "projective

30 See also Potts (2007) and commentaries on that paper in the same journal issue, as well as Amaral et al. (2007). Gutzmann (2008, 5.3.3) presents a more explicit Potts-style treatment of the non-focusability of German modal particles.

${ }^{31}$ However, Persze János majd lediplomázik seems to be preferred over Majd János persze lediplomázik. This would be in line with the predictions from adverbial hierarchies discussed in section 2.1.1: Evidentials per default precede temporals. 
meaning". From this perspective, the ban on persze inside restrictive relatives and standard hypothetical conditionals mentioned in section $\mathbf{2 . 2}$ can be explained. Consider (36). ${ }^{32}$

(36) (a) *Ha János persze lediplomázik, Mária örülni fog. if John vm.graduate.3sg Mary rejoice.inf will.3sg 'If John (*of course) graduates, Mary will be happy'

(b) $\langle[\operatorname{Graduate}(j)] \rightarrow[\operatorname{Happy}(m)]$, Of.Course[ $\operatorname{araduate}(j)]\rangle$

While the at-issue component of (36b) only asserts that a hypothetical graduation by John would have a positive impact on Mary's emotional state, the projective meaning of persze commits the speaker to John's graduation being a matter of course. This leads to a tension that can be made responsible for the unacceptability of $(36 a) .{ }^{33}$

Now, predictions for majd appear to be similar. This is best brought out by using an informationally more unlikely conditional protasis as in (37).

(37) (a) Ha a Nap majd rózsaszínűvé változik, Mária örülni fog. if the sun pink.into turn.3sg Mary rejoice.inf will.3sg 'If the sun turns pink, Mary will be happy'

(b) $\langle[\operatorname{TURN} . \operatorname{Pink}(s)] \rightarrow[\operatorname{HAPpy}(m)]$, SOONER.OR.LATER[TURN.Pink $(s)]\rangle$

The speaker commitment arising from the putative projective meaning of majd seems to be too strong. However, (37a) is acceptable, as is (21a) involving majd in a restrictive relative. To account for this, it would not be enough to consider majd a "hybrid" that contributes both descriptive and projective meanings (cf., e.g., Gutzmann 2011). This is shown in (38).

(38) 〈( $\operatorname{SOONER.OR.LATER}[\operatorname{TURN} . \operatorname{Pink}(s)]) \rightarrow[\operatorname{HAPPy}(m)]$, SOONER.OR.LATER[TURN.Pink $(s)]\rangle$

32 Recall that, as mentioned in section $\mathbf{2 . 2}$, persze and of course would be fine in what Haegeman (2003) calls "premise conditionals". Another reading becomes prominent when persze/of course is placed immediately to the right of the conditional conjunction ha/if: If, of course, John graduates, Mary will be happy. Here, the pragmatic marker can take scope over the entire complex sentence and thus a clash of commitments is avoided: $\langle[\operatorname{GRADUATE}(j)] \rightarrow[\operatorname{HAPPy}(m)]$, OF.COURSE $([\operatorname{GraduATE}(j)] \rightarrow[\operatorname{Happy}(m)])\rangle$.

33 The same account can-mutatis mutandis - be given for the incompatibility of persze with standard information-seeking questions, while compatibility with rhetorical questions, (23) (section 2.2; V-p, section 5), is expected, given that these can be analyzed as indirect assertions (cf., e.g., Meibauer 1986). 
For the sake of simplicity we assume here that majd makes the same contribution in both dimensions. Still, the "projective commitment" remains too strong.

As an alternative, one may search for an account of the non-focusability of majd elsewhere and assume that it only contributes descriptive meaning. Given that majd almost exclusively combines with "futurate" expressions, this contribution is trivial from a truth-conditional perspective. ${ }^{34}$ At the same time, the pragmatic effects associated with majd (cf. Vaskó 2001; K-m) can - at least in part - be assimilated to the "widening" effect of polarity items (Kadmon-Landman 1993) and concomitant "hedging" effects on speech acts. ${ }^{35}$ Thus, clearly, a command like (39a) gets substantially "mitigated" by insertion of a counterpart of majd:

(39) (a) Do your homework!

(b) Do your homework, sooner or later!

Similarly, a promise gets decidedly more "non-committal" by adding majd (I'll do my homework, sooner or later). Also, a difficult-to-make prediction can be rendered less "risky" (You'll recover, sooner or later) and thus be used as comfort in a situation of uncertainty. ${ }^{36}$

${ }^{34}$ Of course, majd must not be taken to introduce a second future operator, as it does not trigger any future-in-future readings. Instead it has to be analyzed like a standard temporal adverb (trivially) restricting the future reference time. On this account, no contradiction arises when majd is combined with mindjárt 'right away', contrary to what is assumed by Kiefer (K-m; section 3). As noted by Vaskó (2001, section 4), majd can also function as a conjunction meaning 'then'. On this use, it may combine with past tense.

35 See Brown-Levinson (1987) for details on hedging. Krifka (1995, 3.5) discusses the impact of polarity items on speech acts.

${ }^{36}$ The difference between plain persze and persze, hogy - not systematically treated by Vaskó $(\mathrm{V}-p)$ - is likely to be attributable to the difference between at-issue meaning and projective meaning, too. Consider (i), where (ib) is modeled on an example by Vaskó (V-p, section 3.1):

(i) (a) Persze, hogy önnek ez kínaiul van. that you.dat this Chinese.in be.3sg

'It is a matter of course that this is Double Dutch for you.'

(b) Persze önnek ez kínaiul van.

'Of course, this must be Double Dutch for you.'

While (ia) treats the addressee's incapability of understanding as an objective $a$ priori, which amounts to an insult, (ib) can be used as excusing the addressee's 


\subsection{Clause types and conversational moves}

In our study of hadd-clauses in section 2.2, we left open certain specifications of the "imperative", i.e., the clause type hadd seems to combine with. In particular, contrary to, e.g., Varga (2012b, 14), we were hesitant to locate anything like a directive illocutionary operator in TypeP. This is due to the fact that Hungarian "imperatives" may occur in bona fide subordination, i.e., the constraint of "limited embeddability" mentioned in section $\mathbf{2 . 2}$ does not (seem to) apply. Consider first the following contrast between Hungarian and English, where (40b) is a direct translation of (40a).
(40) (a) János szerint
fogadd
el az állást.
John according.to take.subj.2sg vm the job.acc
(b) *According to John, take the job!

To express in English what (40a) expresses, one has to use a declarative clause containing a modal verb:

(41) According to John you should take the job.

This difference in "inherent performativity" between Hungarian and English "imperatives" - i.e., for example, the difference between describing a piece of advice and giving advice - is clearly responsible for even starker contrasts like the following. Again, (42b) is an attempt at a direct translation of (42a).

(coincidental) difficulties in understanding. In the latter but not in the former, persze functions as a non-at-issue evidential. The effect is very close to the one discussed by Kratzer $(1981,57)$ wrt the expression of objective vs. subjective probability. It appears that persze in persze, hogy still functions as a response particle presupposing a rather specific "question-under-discussion" (QUD) in the context. That the QUD is essential in defining (non-)at-issueness is exactly the point of view defended by Simons et al. (2010).

Also, persze, hogy is not simply the result of attaching persze to a root hogyclause, as the latter have very specific uses absent from persze, hogy-structures. (ii), for example, expresses a complaint.

(ii) Hogy te mindig elkésel!

that you always vm.be.late.2sg

'Why do you always have to be late!?' 
(42) (a) Senki nem kérte, hogy írd meg a leckéjét. nobody not asked.3sg that write.subj.2sg vm the homework.his.acc

(b) ${ }^{*}$ Nobody $_{\boldsymbol{i}}$ asked (that) do their $\boldsymbol{i}_{\boldsymbol{i}}$ homework.

The bound variable forces the putative Hungarian "imperative" into the scope of negation and prevents a ("colon" plus) direct speech interpretation. Again, for creating a proper counterpart to (42a), English has to resort to a modalized declarative:

(43) Nobody i $_{\boldsymbol{i}}$ asked that you should do their $\boldsymbol{i}$ homework.

Let us therefore assume that what has been called "imperative" in Hungarian is actually some kind of "proto-imperative", i.e., a clause type with the following characteristics: (i) It contains a covert deontic necessity modal, $\square_{d}$, in MP. (ii) Proto-imperative TypeP is underspecified such that (a) the difference between assertive/descriptive uses like (40a) and directive uses like (29a) or Gyere haza! 'Come home!' is derived in exactly the same way that the difference between descriptive and performative modals is derived. ${ }^{37}$ And (b), it is "transparent" for selection by matrix predicates to derive properly subordinated cases like (42a).

Our analysis of Hungarian proto-imperatives bears close resemblance to the analysis of German and English imperatives by Kaufmann (2012). ${ }^{38}$ The latter are taken to essentially involve "graded modals[,] rel[ying] on the idea of endowing imperatives with precisely those presuppositions that describe a context in which an overt necessity modal would be used performatively" (Kaufmann 2012, 163). For Hungarian these presuppositions have to be adjusted such that performative readings are not "hardwired" but can be "accommodated".

As noted by Kaufmann (2012, 6.1; cf. Platzack 2007; Crnic-Trinh 2011), imperatives in Germanic languages do allow a specific kind of "embedding", i.e., they can provide the content of speech and thought representation as arguments of predicates like say, ask, and request. ${ }^{39}$

${ }^{37}$ For some recent discussion, see Portner (2009, 4.3.3). That Hungarian "imperatives" must be able to acquire what Platzack and Rosengren (1998) call "referring" readings is also noted by Varga (2012b, 8).

38 The roughly sketched approach to Hungarian "imperatives" by Farkas (1992, 2223) can potentially be understood as a predecessor designed in a similar spirit.

${ }^{39}$ Interestingly, Hungarian "imperatives" do not in general allow conditional readings, i.e., they do not function as "pseudo-imperatives". Thus, (i) is decidedly odd: 
These, however, have to be analyzed as "dependent main clause phenomena" in which the selecting predicates "spell out" the illocutionary operator reportedly used in the source situation. In Hungarian, the hallmark of such uses is the option of complementizer-drop (cf., e.g., Kenesei $1994,5.1)$. Tóth $(2006,125,127)$ seems to take this to be a general feature of Hungarian "imperatives" in complement position, offering examples like (44) (glossing and translation adjusted; HMG \& BGy).

(44) Azt javaslom, (hogy) olvasd el a könyvet.

that.acc suggest.1sg that read.subj.2sg vm the book.acc

'I suggest that you read the book.'

Complementizer-drop, however, is not an option in the case of (43), which we take as additional argument that we are dealing with a case of standard subordination there. ${ }^{40,41}$

(i) \#Törd el a lábad egy rossz pillanatban

break.subj.2sg vm the leg.your one bad moment.in

és vége az atléta-karrierednek.

and end.poss.3sg the athlete-career.your.dat

'Break your leg in the wrong moment and your career as an athlete is finished.'

Quite tellingly, the effect in (i) is similar to ${ }^{\#}$ You should break your leg in the wrong moment and your career as an athlete is finished (cf. Kaufmann 2012, 242). For some reason to be further explored, (i) improves if the "imperative" contains csak egyszer 'only once'. For the role of "minimizers" in pseudo-imperatives, see ibid., 6.3.1.3.

40 The discussion of "embedded root phenomena" goes back at least to HooperThompson (1973; see Heycock 2006 for an overview and Aelbrecht et al. 2012 for some recent studies). It is clear from that work that different kinds of main clause phenomena have to be distinguished. Among clause types there seems to be a hierarchy (declarative $>$ interrogative $>$ imperative) going from most to least accessible for the kind of "context shift" involved in these environments.

${ }^{41}$ An interesting case of dependent proto-imperative is presented by Farkas (1992, 217):

(i) Mari meggyőzte Pétert, hogy menjen el.

Mary vm.convinced.3sg Peter that go.subj.3sg vm

'Mary convinced Peter to leave.'

In contrast with a communication verb like tell, convince is denotationally related to the perlocutionary effect of a speech act. Thus, this verb does not figure as "parenthetical verb" (cf. Urmson 1952) in reported speech: "Leave now!", Mary told Peter / *Leave now!", Mary convinced Peter. In fact, the Hungarian counterpart of convince can embed proto-imperatives in descriptions of situations not involving any speech act. And, crucially, complementizer-drop is prohibited there: 
Curiously, underspecification of proto-imperative TypeP is even compatible with the licensing of interrogative $-e$ (discussed in section $\mathbf{2 . 2}$ above), as shown in (45a). ${ }^{42}$

(45) (a) Mikor fogod végre megkérdezni, hogy hozzál-e be egy kávét? when will.2sg finally vm.ask.inf that bring.subj.2sg-e vm a coffee.acc

(b) *When are you finally going to ask whether bring a coffee?

(c) When are you finally going to ask whether you should bring a coffee?

Attempted and proper translation in (45b) and (45c) confirm the by now familiar difference between Hungarian proto-imperatives and English imperatives.

Let us now briefly return to hadd-clauses. Replacing $\square_{d}$ in MP by hadd does not in principle affect embeddability, as examples (40) and (42a) can mutatis mutandis be reproduced with hadd. However, there is greater selectivity, since interrogative specification of TypeP in haddclauses is ruled out:

(46) *(Megkérdeztem, hogy) hadd menjek-e ki. vm.asked.1sg that go.subj.1sg-e vm

'I asked whether I would be allowed to go out.'/'Am I allowed to go out?'

(ii) János egy pofonnal meggyőzte Pétert, *(hogy) álljon félre. John a slap.with vm.convinced.3sg Peter.acc that stand.subj.3sg vm 'John convinced Peter with a slap that he should stand aside.'

For a comprehensive list of predicates compatible with "imperative" complements, see Tóth $(2006,5.2)$.

42 2nd-person -e-marked proto-imperatives are rather rare (and stylistically marked). Another example we could come up with uses the "reflective" question particle vajon in addition (see below), making the question act self-addressed or even a matter of internal thought:

(i) Vajon ismerjétek-e meg a nehézségeket?

get.to.know.subj.2pl-e vm the difficulties.acc

'I wonder whether you should face the vicissitudes of life.'

Non-2nd-person cases can be found in the Hungarian National Corpus. (45a) and (i) cast doubt on the suggestion by Turi $(2009,36)$ to reanalyze what look like intonationally marked polar interrogatives involving "imperatives" as noninterrogative complements of a hidden matrix predicate.

Kaufmann $(2012,2.3 .3 .3)$ presents evidence for German imperatives in "rhetorically" used wh-interrogatives. We think that these cases are "echoic" and therefore licensed by a different kind of mechanism. 
In line with standard views on grammaticalization, Péteri $(\mathrm{P}-h)$ makes a particular case for considering hadd semantically "abstract" in many of its uses. Szücs (2010, 211; cf. Hollos-Beeman 1978, 347-8), on the other hand, defends an analysis built on the meaning component 'ask for permission' carrying over from the original verb hagy. A piece of evidence potentially weighing in favor of the latter view comes from a comparison with the English let's-construction (cf., e.g., Clark 1993). Thus, expositive, (47a), and "stimulating", (47b), uses of let's, which are clearly abstracted from-or "preempt" - asking for permission, cannot be replicated with Hungarian hadd but have to be expressed as in (48).

(47) (a) Let's be quite clear about this.

(b) Let's get some ice cream.

(48) (a) Tisztázzuk ezt! clean.subj.1pl this.acc

(b) Vegyünk egy fagylaltot! buy.subj.1pl an ice.cream.acc

Adding hadd to these direct renderings of (47) would clearly change them into requests for permission. ${ }^{43}$

Structurally, both proto-imperatives and hadd-clauses involve verbvm-inversion, which we interpret as verb movement from Pred $^{0}$ to Fin ${ }^{0}$ (see section 2.2). In the absence of hadd, main clauses involving a "noninverted" subjunctive verb are also attested. É. Kiss $(2011,101)$ takes structures like (49) to be optional alternatives of standard "imperatives".

(49) Haza-gyere!

home-come.subj.2sg

However, use of such forms is specifically restricted to situations where one reminds the addressee of a directive already given or where one appeals to the obvious validity of that directive. This is reminiscent of the use of German dass 'that' + V-final clauses (cf. Oppenrieder 1989; Truckenbrodt to appear). We therefore think that (49) is a case of "insubordination" (cf. Evans 2007) based on a standardly subordinate subjunctive

43 To the extent that it makes sense to speak of 1st-person directives/hortatives in the case of hadd ( $\mathrm{P}-h$, section $\mathbf{2}$ ), there is a clear link to (the flouting of) the second preparatory condition on directives stated by Searle $(1969,66)$ : "It is not obvious to both $S$ and $H$ that $H$ will do $A$ in the normal course of events of his own accord." The exact pragmatics of this remains to be sorted out.

Acta Linguistica Hungarica 59, 2012 
clause. A satisfactory formal account of this construction has to await further research.

We will finish our remarks by returning to the pragmatic marker vajon, which we discussed in section $\mathbf{2 . 2}$. There we provided (further) evidence that vajon gets inserted into interrogatives. Here we would like to look at a slightly more formal way of treating its impact on the conversational moves triggered by interrogatives. Informally, this impact is quite adequately describable in terms of Lyons $(1977,755)$, who proposed "a distinction between asking a question of someone and simply posing the question (without necessarily addressing it to anyone). When we pose a question, we merely give expression to, or externalize, our doubt; and we can pose questions which we do not merely expect to remain unanswered, but which we know, or believe, to be unanswerable." We suggest that with vajon-interrogatives, the specific acts involved in posing such questions "that seek no answer" (Maynard 1995) ${ }^{44}$ should be called "reflective". To illustrate the effect we give two examples. First, think of how interaction with your computer's operating system is organized. When you select to shut the computer down you get confronted with the following kind of message:

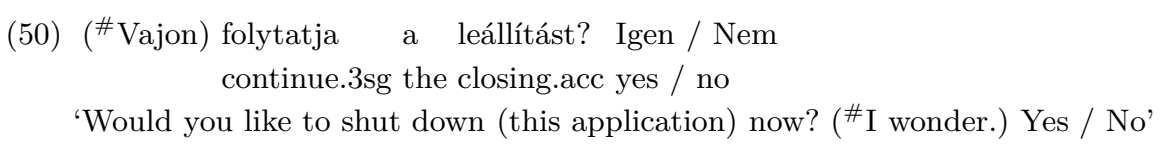

Addition of vajon in (50) is odd because it signals that the computer, rather than seeking your (dis)confirmation, has begun to freely and openendedly reflect on the issue whether or not it should be shut down. Similarly, the dialog in (51) — adapted from Truckenbrodt $(2006,274)$ - is anomalous without vajon, given that B has signaled already that he/she is unable to provide any information.

(51) A: Have you been in touch with John lately?

B: Not at all.

A: \#(Vajon) elvégezte már az egyetemet? vm.finished.3sg already the university.acc 'Has he already received his degree? \# (I wonder.)"

${ }^{44}$ Related types have been called "dubitative questions" (Rakić 1984), "speculative questions" (Wilson-Sperber 1988), "deliberative questions" (Oppenrieder 1989), or "self-addressed questions" (Jang 1999). 
Addition of vajon in (51), on the other hand, "puts the question on the table" without request for an answer.

It is exactly the idea just mentioned that has been formalized for the Romanian counterpart construction, oare-interrogatives, by Farkas and Bruce (2009). In a simplified form, their discourse model consists of (i) a set $C G$ ("common ground") of propositions shared as joint discourse commitments by all participants, (ii) a stack of sentential form/meaning pairs called "Table", and (iii) a set PS ("projected set") of "projected" or "privileged" future common grounds. "The Table records what is "at issue' in the conversation. When the Table is not empty, the immediate goal of the conversation is to empty it, that is, to settle the issue at hand. [...] A conversation is in a stable state when its Table is empty" (ibid., 87). In that system, the initial conversational move involving an assertively used declarative sentence, $S_{\mathrm{DEC}}$, looks as follows:

(52) (a) $\left\langle S_{\mathrm{DEC}},\left\{p_{\mathrm{S}}\right\}\right\rangle$ is pushed onto the Table

(b) Every member of the projected set $P S$ is updated with $p_{\mathrm{S}}$

In the null context, the input projected set $P S_{i}$ contains just the empty input common ground, $C G_{i}$, i.e., $P S_{i}=\left\{C G_{i}\right\}=\{\emptyset\}$. So after the update in $(52 \mathrm{~b})$ we have the temporary projected set $P S_{t}=\left\{\left\{p_{\mathrm{s}}\right\}\right\}$. In case of "confirmation", i.e., if the assertion of $\left\langle S_{\mathrm{DEC}},\left\{p_{\mathrm{S}}\right\}\right\rangle$ is accepted by the interlocutor(s), a further update is made which crucially yields a new (output) common ground, $C G_{\mathrm{o}}$ :

(53) (a) $\left\langle S_{\mathrm{DEC}},\left\{p_{\mathrm{S}}\right\}\right\rangle$ is removed from the Table

(b) $C G_{\mathrm{O}}=C G_{i} \cup\left\{p_{\mathrm{S}}\right\}$

Standard "erotetic" use of a polar interrogative, $S_{\text {INT }}$, yields the following initial context change:

(54) (a) $\left\langle S_{\text {INT }},\left\{p_{\mathrm{S}}, \neg p_{\mathrm{S}}\right\}\right\rangle$ is pushed onto the Table

(b) Every member of the projected set $P S$ is copied;

then one copy is updated with $p_{\mathrm{S}}$, the other with $\neg p_{\mathrm{S}}$

In the null context this will result in the temporary projected set $P S_{t}=$ $\left\{\left\{p_{\mathrm{S}}\right\},\left\{\neg p_{\mathrm{S}}\right\}\right\}$. Depending on confirmation ('yes') or rejection ('no'), the common ground will be updated accordingly.

Finally, "reflective" use of a polar interrogative, $S_{\mathrm{INT}}$, such as triggered by vajon, defines the following initial conversational move: 
(55) (a) $\left\langle S_{\mathrm{INT}},\left\{p_{\mathrm{S}}, \neg p_{\mathrm{S}}\right\}\right\rangle$ is pushed onto the Table

(b) Every member of the projected set $P S$ is copied twice; then one copy is updated with $p_{\mathrm{S}}$, another with $\neg p_{\mathrm{S}}$, and a third copy is left unchanged

Thus, in the null context, the temporary projected set resulting from a "reflective" question act is $P S_{t}=\left\{\left\{p_{\mathrm{S}}\right\},\left\{\neg p_{\mathrm{S}}\right\}, \emptyset\right\}$. That is, use of, e.g., vajon-interrogatives signals that in one of the projected future discourse states the common ground is left unchanged. ${ }^{45}$ By an additional standard Gricean reasoning step, this unchanged future common ground will have to be taken as "privileged", given that the speaker could have left out vajon and triggered the move in (54) instead of the one in (55).

Obviously, more elaborate models will have to be developed to capture more complicated phenomena. ${ }^{46}$ One notoriously difficult question is the treatment of indirect speech acts. Thus, while German $o b+w o h l+\mathrm{V}$-final interrogatives, which are canonically used for reflective question acts, can be employed to convey (polite) requests (Oppenrieder 1989, 182), the corresponding indirect use of vajon-interrogatives is infelicitous:

${ }^{45}$ In addition to response particles answering questions positively ( $j a$ ) and negatively (nein), German possesses the particle tja, the use of which is adequate in exactly the situation where a reflective question is on the table and one wants to leave the issue open. This is presumably related to the "express[ion] of hesitation and resignation" described by Aijmer and Simon-Vandenbergen $(2003,1153)$ for the homophonous Dutch and Swedish counterparts of tja (cf. Métrich-Faucher 2009, 854).

46 See for example the treatment of "rhetorical relations" by Asher-Lascarides (2003), superlative quantifiers and "meta-speech acts" by Cohen-Krifka (2011), and (full-fledged) dialog by Ginzburg (2012). Speech act combining or "embedding" is another issue to be investigated further. In line with work by Krifka (2001) and McCloskey (2006), an analysis of vajon in terms of conversational moves predicts that it should only be licensed in dependent clauses that (indirectly) encode such a move. The following contrast between intensional and extensional matrix verbs for vajon-interrogatives confirms this:

(i) (a) Azon tünődöm, hogy János (vajon) vett-e kenyeret. that.on wonder.1sg that John bought- $e$ bread.acc

'I wonder whether John bought bread.'

(b) Tudom, hogy János ( ${ }^{*}$ vajon) vett-e kenyeret.

know.1sg that John bought- $e$ bread.acc

'I know whether John bought bread (\# I wonder).' 
(56) (a) Ob Du mir wohl (mal) die Tür öffnen könntest? whether you I.dat $\mathrm{mp}$ once the door open could.2sg 'Do you think you could open the door for me?'

(b) ("Vajon) Ki tudnád nyitni az ajtót? vm can.cond.2sg open.inf the door.acc 'Could you open the door? ("I wonder.)'

Apparently, the literal reflective effect of vajon blocks computation of a serious indirect request, a phenomenon variously discussed in the debate on conventionalization and short-circuiting involved in indirect speech acts (cf., e.g., Asher-Lascarides 2001).

\section{References}

Adger, David - Cécile de Cat-George Tsoulas (eds) 2004. Peripheries: Syntactic edges and their effects. Kluwer, Dordrecht.

Aelbrecht, Lobke-Liliane Haegeman - Rachel Nye (eds) 2012. Main clause phenomena. John Benjamins, Amsterdam \& Philadelphia.

Aijmer, Karin-Anne-Marie Simon-Vandenbergen 2003. The discourse particle well and its equivalents in Swedish and Dutch. In: Linguistics 41:1123-61.

Aijmer, Karin-Anne-Marie Simon-Vandenbergen (eds) 2006. Pragmatic markers in contrast. Elsevier, Amsterdam.

Aijmer, Karin-Anne-Marie Simon-Vandenbergen 2009. Pragmatic markers. In: JanOla Östman - Jef Verschueren (eds): Handbook of pragmatics. John Benjamins, Amsterdam \& Philadelphia. http://www.benjamins.nl/online/hop

Alexiadou, Artemis 1997. Adverb placement. John Benjamins, Amsterdam \& Philadelphia.

Altmann, Hans 1993. Satzmodus. In: Joachim Jacobs-Arnim von Stechow-Wolfgang Sternefeld - Theo Vennemann (eds): Syntax. Ein internationales Handbuch zeitgenössischer Forschung, 1006-29. Walter de Gruyter, Berlin.

Amaral, Patricia - Craige Roberts - E. Allyn Smith 2007. Review of 'The logic of conventional implicatures' by Chris Potts. In: Linguistics and Philosophy 30 : 707-49.

Antal, László 1975. Két karcolat a leíró nyelvészet köréből [Two sketches in descriptive grammar]. In: Magyar Nyelv 71:40-6.

Asher, Nicholas - Alex Lascarides 2001. Indirect speech acts. In: Synthese 128:183-228.

Asher, Nicholas-Alex Lascarides 2003. Logics of conversation. Cambridge University Press, Cambridge.

Bartos, Huba 2002. Root infinitives. In: Kenesei-Siptár (2002, 11-38).

Bayer, Josef 2001. Asymmetry in emphatic topicalization. In: Caroline Féry - Wolfgang Sternefeld (eds): Audiatur vox sapientiae: A Festschrift for Arnim von Stechow, 15-47. Akademie Verlag, Berlin.

Acta Linguistica Hungarica 59, 2012 
Bayer, Josef-Hans-Georg Obenauer 2011. Discourse particles, clause structure, and question types. In: The Linguistic Review 28:449-91.

Benincà, Paola - Nicola Munaro (eds) 2011. Mapping the left periphery. Oxford University Press, Oxford.

Benincà, Paola - Cecilia Poletto 2004. Topic, focus and V2: Defining the CP sublayers. In: Rizzi (2004, 52-75).

Bhatt, Rakesh-James Yoon 1992. On the composition of Comp and parameters of V2. In: Dawn Bates (ed.): Proceedings of WCCFL X, 41-52. CSLI Publications, Stanford.

Blakemore, Diane 2004. Discourse markers. In: Laurence R. Horn - Gregory Ward (eds): The handbook of pragmatics, 221-40. Blackwell, Oxford \& Malden MA.

Błaszczak, Joanna-Hans-Martin Gärtner 2005. Intonational phrasing, discontinuity, and the scope of negation. In: Syntax 8:1-22.

Brinton, Laurel 2010. Discourse markers. In: Andreas Jucker - Irma Taavitsainen (eds): Historical pragmatics, 285-314. De Gruyter Mouton, Berlin.

Brody, Michael 1990. Remarks on the order of elements in the Hungarian focus field. In: István Kenesei (ed.): Approaches to Hungarian 3: Structures and arguments, 95-121. JATE, Szeged.

Brody, Michael-Kriszta Szendrői 2010. Exhaustive focus is an answer. http://ling.auf.net/lingBuzz/001113

Brown, Penelope-Stephen C. Levinson 1987. Politeness: Some universals in language usage. Cambridge University Press, Cambridge.

Büring, Daniel 1997. The great scope inversion conspiracy. In: Linguistics and Philosophy $20: 175-94$.

Cardinaletti, Anna-Ian Roberts 2002. Clause structure and X-second. In: Guglielmo Cinque (ed.): Functional structure in DP and IP, 123-66. Oxford University Press, Oxford.

Cheng, Lisa Lai-Shen 1991. On the typology of wh-questions. Doctoral dissertation, MIT.

Chomsky, Noam 1986. Barriers. MIT Press, Cambridge MA.

Cinque, Guglielmo 1999. Adverbs and functional heads: A cross-linguistic perspective. Oxford University Press, Oxford.

Clark, Billy 1993. Let and let's: Procedural encoding and explicature. In: Lingua 90 : 173-200.

Cohen, Ariel-Manfred Krifka 2011. Superlative quantifiers as modifiers of meta-speech acts. In: Barbara Partee-Michael Glanzberg-Jurgis Skilters (eds): The Baltic international yearbook of cognition, logic and communication, 1-56. New Prairie Press, Manhattan KS.

Coniglio, Marco 2011. Die Syntax der deutschen Modalpartikeln. Akademie Verlag, Berlin.

Craenenbroeck, Jeroen van-Anikó Lipták 2008. On the interaction between verb movement and ellipsis: New evidence from Hungarian. In: WCCFL 26 : 138-46.

Crnic, Luka-Tue Trinh 2011. Embedding imperatives. In: NELS 39. 
Dalmi, Gréte 2012. Hungarian vajon: Whether a complementizer or a scope-marker? In: Anna Bloch-Rozmej-Maria Bloch-Trojnar (eds): SLAM 5: Modules and interfaces, 113-37. Wydawnictwo Katolickiego Uniwersytetu Lubelskiego, Lublin.

Dikken, Marcel den 2004. Agreement and "clause union". In: Katalin É. Kiss-Henk van Riemsdijk (eds): Verb clusters. A Study of Hungarian, German and Dutch, 445-98. John Benjamins, Amsterdam \& Philadelphia.

Dér, Csilla Ilona 2010. On the status of discourse markers. In: Acta Linguistica Hungarica $57: 3-28$.

Egedi, Barbara 2009. Adverbial (dis)ambiguities. Syntactic and prosodic features of ambiguous predicational adverbs. In: É. Kiss (2009a, 103-32).

É. Kiss, Katalin 2002. The syntax of Hungarian. Cambridge University Press, Cambridge.

É. Kiss, Katalin 2008. Topic and focus: Two structural positions associated with logical functions in the left periphery of the Hungarian sentence. In: Acta Linguistica Hungarica $55: 287-96$.

É. Kiss, Katalin (ed.) 2009a. Adverbs and adverbial adjuncts at the interfaces. Mouton de Gruyter, Berlin \& New York.

É. Kiss, Katalin 2009b. Introduction. In: É. Kiss (2009a, 1-18).

É. Kiss, Katalin 2009c. Syntactic, semantic, and prosodic factors determining the position of adverbial adjuncts. In: É. Kiss (2009a, 21-38).

É. Kiss, Katalin 2011. On a type of counterfactual construction. In: Tibor LaczkóCatherine O. Ringen (eds): Approaches to Hungarian 12: Papers from the 2009 Debrecen conference, 85-107. John Benjamins, Amsterdam \& Philadelphia.

Ernst, Thomas 2002. The syntax of adverbs. Cambridge University Press, Cambridge.

Ernst, Thomas 2007. On the role of semantics in a theory of adverb syntax. In: Lingua $117: 1008-33$.

Evans, Nicholas 2007. Insubordination and its uses. In: Irina Nikolaeva (ed.): Finiteness, 366-431. Oxford University Press, Oxford.

Farkas, Donka 1992. Mood choice in complement clauses. In: István Kenesei-Csaba Pléh (eds): Approaches to Hungarian 4: The structure of Hungarian, 207-25. JATE, Szeged.

Farkas, Donka-Kim Bruce 2009. On reacting to assertions and polar questions. In: Journal of Semantics $27: 81-118$.

Fábricz, Károly 1985. Az is mint kötőszó és mint partikula [Is as a conjunction and as a particle]. In: Magyar Nyelv $81: 79-87$.

Fischer, Kerstin (ed.) 2006. Approaches to discourse particles. Elsevier, Oxford.

Foolen, Ad 1996. Pragmatic particles. In: Jef Verschueren - Jan-Ola Östman - Jan Blommaert-Chris Bulcean (eds): Handbook of pragmatics: 1996 installment, 1-24. John Benjamins, Amsterdam \& Philadelphia.

Fraser, Bruce 1988. Types of English discourse markers. In: Acta Linguistica Hungarica $38: 19-33$.

Fraser, Bruce 1990. An approach to discourse markers. In: Journal of Pragmatics 14: 383-95. 
Fraser, Bruce 1996. Pragmatic markers. In: Pragmatics 6:167-90.

Fraser, Bruce 1999. What are discourse markers? In: Journal of Pragmatics 31 : 931-52.

Frey, Werner 2004. A medial topic position for German. In: Linguistische Berichte 198 : 153-90.

Gécseg, Zsuzsanna 2006. Topic, logical subject and sentence structure in Hungarian. In: Acta Linguistica Hungarica 53:139-74.

Gécseg, Zsuzsanna-Ferenc Kiefer 2009. A new look at information structure in Hungarian. In: Natural Language and Linguistic Theory $27: 583-622$.

Ginzburg, Jonathan 2012. The interactive stance. Oxford University Press, Oxford.

Grewendorf, Günther 2002. Minimalistische Syntax. Francke Verlag, Tübingen.

Groot, Casper de 2010. Mood in Hungarian. In: Björn Rothstein-Rolf Thieroff (eds): Mood in the languages of Europe, 551-67. John Benjamins, Amsterdam \& Philadelphia.

Gunlogson, Christine 2003. True to form: Rising and falling declaratives as questions in English. Routledge, New York.

Gunlogson, Christine 2008. A question of commitment. In: Belgian Journal of Linguistics $22: 101-36$.

Gutzmann, Daniel 2008. On the interaction between modal particles and sentence mood in German. MA thesis, University of Mainz.

Gutzmann, Daniel 2011. Expressive modifiers and mixed expressives. In: Empirical Issues in Syntax and Semantics $8: 123-41$.

Gyuris, Beáta 2008. A diskurzus-partikulák formális vizsgálata felé [Towards a formal investigation of discourse particles]. In: Ferenc Kiefer (ed.): Strukturális magyar nyelvtan 4. A szótár szerkezete [A structural grammar of Hungarian 4. The structure of the lexicon], 639-82. Akadémiai Kiadó, Budapest.

Gyuris, Beáta 2009a. The interpretation of a contrast-marking particle. In: Current issues in unity and diversity of languages. Collection of the papers selected from the CIL 18. LSK (The Linguistic Society of Korea), Seoul. (CD-ROM).

Gyuris, Beáta 2009b. The semantics and pragmatics of the contrastive topic in Hungarian. Lexica, Budapest.

Haegeman, Liliane 2003. Conditional clauses: External and internal syntax. In: Mind and Language 18:317-39.

Haegeman, Liliane 2006. Conditionals, factives and the left periphery. In: Lingua 116 : $1651-69$.

Haegeman, Liliane 2007. Operator movement and topicalization in adverbial clauses. In: Folia Linguistica 18:485-502.

Haegeman, Liliane 2010a. The internal syntax of adverbial clauses. In: Lingua 120: $628-48$.

Haegeman, Liliane 2010b. The movement derivation of conditional clauses. In: Linguistic Inquiry $41: 595-621$.

Haegeman, Liliane 2012. The syntax of MCP: Deriving the truncation account. In: Aelbrecht et al. (2012, 113-34).

Harden, Theo-Elke Hentschel (eds) 2010. 40 Jahre Partikelforschung. Stauffenburg, Tübingen. 
Heim, Irene 1992. Presupposition projection and the semantics of attitude verbs. In: Journal of Semantics 9:183-221.

Heine, Bernd - Tania Kuteva (eds) 2002. World lexicon of grammaticalization. Cambridge University Press, Cambridge.

Hentschel, Elke- Harald Weydt 2002. Die Wortart „Partikel“. In: D. Alan Cruse-Franz Hundsnurscher-Michael Job-Rolf Peter Lutzeier (eds): Lexikologie. Ein internationales Handbuch zur Natur und Struktur von Wörtern und Wortschätzen, 646-53. de Gruyter, Berlin.

Heycock, Caroline 2006. Embedded root phenomena. In: Martin Everaert-Henk van Riemsdijk (eds): The Blackwell companion to syntax, 174-209. Blackwell, Malden MA \& Oxford.

Hill, Virginia 2002. Complementizer phrases (CP) in Romanian. In: Rivista di Linguistica $14: 223-48$.

H. Molnár, Ilona 1959. A módosító szók mondattani arculatának kérdéséhez [Towards the syntactic properties of modifying words]. In: Magyar Nyelv $55: 357-61,470$ 80 .

Hollos, Marida-William Beeman 1978. The development of directives among Norwegian and Hungarian children: An example of communicative style in culture. In: Language in Society $7: 345-55$.

Hooper, Joan-Sandra Thompson 1973. On the applicability of root transformations. In: Linguistic Inquiry 4:465-97.

Horvath, Julia 2010. "Discourse features", syntactic displacement and the status of contrast. In: Lingua 120:1346-69.

Horváth, Katalin-Attila Péteri 2005. Das Satzmodussystem im Deutschen und im Ungarischen. In: Magdolna Orosz-Terrance Albrecht (eds): Jahrbuch der ungarischen Linguistik 2004, 185-220. Gondolat, Budapest.

Jackendoff, Ray 1972. Semantic interpretation in generative grammar. MIT Press, Cambridge MA.

Jang, Youngjun 1999. Two types of question and existential quantification. In: Linguistics $37: 847-69$.

Juhász, Dezső 1991. A módosítószók [Modifying words]. In: Loránd Benkő-Erzsébet E. Abaffy-Endre Rácz (eds): A magyar nyelv történeti nyelvtana. 1. kötet: A korai ómagyar kor és előzményei [A historical grammar of Hungarian. Volume 1: Early Old Hungarian and its antecedents], 501-13. Akadémiai Kiadó, Budapest.

Kadmon, Nirit - Fred Landman 1993. Any. In: Linguistics and Philosophy 16:353-422.

Kálmán, László 2001. Magyar leíró nyelvtan. Mondattan I [Hungarian descriptive grammar. Syntax 1] (Segédkönyvek a nyelvészet tanulmányozásához VI [Supplementary textbooks on linguistics 6]). Tinta Könyvkiadó, Budapest.

Kántor, Gergely 2008. On Hungarian relative operators. In: The Even Yearbook 8. http://seas3.elte.hu/delg/publications/even/2008.html

Karttunen, Lauri 1973. Presuppositions of compound sentences. In: Linguistic Inquiry $4: 169-93$.

Kaufmann, Magdalena 2012. Interpreting imperatives. Springer, Heidelberg.

Kayne, Richard S. 1998. Overt vs. covert movement. In: Syntax 1:128-91.

Acta Linguistica Hungarica 59, 2012 
Kenesei, István 1992. Az alárendelt mondatok szerkezete [The structure of embedded sentences]. In: Ferenc Kiefer (ed.): Strukturális magyar nyelvtan 1. Mondattan [A structural grammar of Hungarian 1. Syntax], 529-713. Akadémiai Kiadó, Budapest.

Kenesei, István 1994. Subordinate clauses. In: Kiefer-É. Kiss (1994, 275-354).

Kenesei, István-Péter Siptár (eds) 2002. Approaches to Hungarian 8: Papers from the Budapest conference. Akadémiai Kiadó, Budapest.

Kiefer, Ferenc 2005. Lehetőség és szükségszerûség. Tanulmányok a nyelvi modalitás körébõl [Possibility and necessity. Studies in linguistic modality]. Tinta Könyvkiadó, Budapest

Kiefer, Ferenc-Katalin É. Kiss 1994. The syntactic structure of Hungarian. Academic Press, New York.

König, Ekkehard-Peter Siemund 2007. Speech act distinctions in syntax. In: Timothy Shopen (ed.): Language typology and syntactic description. Volume I: Clause structure, 276-324. Cambridge University Press, Cambridge.

Kratzer, Angelika 1981. The notional category of modality. In: Hans-Jürgen Eikmeyer-Hannes Rieser (eds): Words, worlds, and contexts: New approaches to word semantics, 38-74. Walter de Gruyter, Berlin.

Krifka, Manfred 1995. The semantics and pragmatics of polarity items. In: Linguistic Analysis 25: 1-49.

Krifka, Manfred 1998. Scope inversion under the rise-fall contour in German. In: Linguistic Inquiry 29:75-112.

Krifka, Manfred 2001. Quantifying into question acts. In: Natural Language Semantics $9: 1-40$.

Lenk, Uta 1997. Discourse markers. In: Jef Verschueren - Jan-Ola Östman - Jan Blommaert-Chris Bulcean (eds): Handbook of pragmatics: 1997 installment. John Benjamins, Amsterdam \& Philadelphia.

Lipták, Anikó 2001. On the syntax of wh-items in Hungarian. Doctoral dissertation, LOT, Leiden.

Lipták, Anikó 2011. The structure of the topic field in Hungarian. In: Benincà-Munaro (2011, 163-98).

Lohnstein, Horst-Susanne Trissler (eds) 2004. The syntax and semantics of the left periphery. Mouton de Gruyter, Berlin \& New York.

Lyons, John 1977. Semantics. Volume 2. Cambridge University Press, Cambridge.

Maleczki, Márta 2001. Indefinite arguments in Hungarian. In: István Kenesei (ed.): Argument structure in Hungarian, 157-99. Akadémiai Kiadó, Budapest.

Maynard, Senko 1995. Interrogatives that seek no answers: Exploring the expressiveness of rhetorical interrogatives in Japanese. In: Linguistics $33: 501-30$.

McCloskey, James 2006. Questions and questioning in a local English. In: Raffaella Zanuttini-Héctor Campos-Elena Herburger-Paul Portner (eds): Crosslinguistic research in syntax and semantics. Negation, tense, and clausal architecture, 87-126. Georgetown University Press, Washington, D.C.

Meibauer, Jörg 1986. Rhetorische Fragen. Niemeyer, Tübingen. 
Métrich, René-Eugène Faucher 2009. Wörterbuch deutscher Partikeln. De Gruyter, Berlin.

Müller, Gereon-Wolfgang Sternefeld 1993. Improper movement and unambiguous binding. In: Linguistic Inquiry $24: 461-507$.

Oppenrieder, Wilhelm 1989. Selbständige Verb-Letzt-Sätze. In: Hans Altmann - Anton Batliner - Wilhelm Oppenrieder (eds): Zur Intonation von Modus und Fokus im Deutschen, 163-244. Niemeyer, Tübingen.

Ouhalla, Jamal 1991. Functional categories and parametric variation. Routledge, London.

Pasch, Renate-Ursula Brauße-Eva Breindl-Ulrich Hermann Waßner 2003. Handbuch der deutschen Konnektoren. De Gruyter, Berlin.

Péter, Mihály 1991. A nyelvi érzelemkifejezés eszközei és módjai [Means and devices of the expression of emotions in language]. Tankönyvkiadó, Budapest.

Péteri, Attila 2002. Abtönungspartikeln im deutsch-ungarischen Vergleich. Asteriskos, Budapest.

Platzack, Christer 2007. Embedded imperatives. In: Wim van der Wurff (ed.): Imperative clauses in generative grammar, 181-203. John Benjamins, Amsterdam \& Philadelphia.

Platzack, Christer-Inger Rosengren 1998. On the subject of imperatives. In: Journal of Comparative Germanic Linguistics 1:177-224.

Poletto, Cecilia - Jean-Yves Pollock 2004. On wh-clitics and wh-doubling in French and some North Eastern Italian dialects. In: Probus 16 : 241-72.

Pollock, Jean-Yves. 1989. Verb movemet, universal grammar and the structure of IP. In: Linguistic Inquiry $20: 365-424$.

Portner, Paul 2009. Modality. Oxford University Press, Oxford.

Poschmann, Claudia 2008. All declarative questions are attributive? In: Belgian Journal of Linguistics $22: 247-69$.

Potts, Christopher 2005. The logic of conventional implicatures. Oxford University Press, Oxford.

Potts, Christopher 2007. The expressive dimension. In: Theoretical Linguistics 33: 165-98.

Prószéky, Gábor 1989. Határozók, szabad határozók [Adverbials, free adverbials]. In: Általános Nyelvészeti Tanulmányok $17: 213-40$.

Rakić, Stanimir 1984. Serbo-Croatian yes/no-questions and speech acts. In: Journal of Pragmatics 8:693-713.

Reinhart, Tanya 1981. Pragmatics and linguistics. An analysis of sentence topics. In: Philosophica $27: 53-94$.

Rizzi, Luigi 1997. The fine structure of the left periphery. In: Liliane Haegeman (ed.): Elements of grammar, 281-337. Kluwer, Dordrecht.

Rizzi, Luigi (ed.) 2004. The structure of CP and IP. Oxford University Press, Oxford.

Romero-Trillo, Jesús 2009. Discourse markers. In: Jacob Mey (ed.): Concise encyclopedia of pragmatics (2nd ed.), 191-4. John Benjamins, Amsterdam \& Philadelphia. 
Sasse, Hans-Jürgen 1993. Syntactic categories and subcategories. In: Joachim JacobsArnim von Stechow - Wolfgang Sternefeld - Theo Vennemann (eds): Syntax. Ein internationales Handbuch zeitgenössischer Forschung, 646-86. de Gruyter, Berlin.

Schiffrin, Deborah 2003. Discourse markers: Language, meaning, and context. In: Deborah Schiffrin-Deborah Tannen-Heidi E. Hamilton (eds): The handbook of discourse analysis, 54-75. Blackwell, Malden MA \& Oxford.

Schourup, Lawrence 1999. Discourse markers. Tutorial overview. In: Lingua 107 : 227-65. Searle, John R. 1969. Speech acts. Cambridge University Press, Cambridge.

Shaer, Benjamin - Philippa Cook-Werner Frey-Claudia Maienborn (eds) 2009. Dislocated elements in discourse. Routledge, London.

Shlonsky, Ur 2010. The cartographic enterprise in syntax. In: Language and Linguistics Compass $4: 417-29$.

Simoncsics, Péter 2003. Egy uráli párhuzamosság: a nyenyec költői dikció ngey (ngcy) töltőeleme és a magyar -É szintaktomorféma [A Uralic parallel: The Nenets ngey (ngcy) expletive of poetic diction and the Hungarian -É syntactomorpheme]. In: Nyelvtudományi Közlemények 100 : 238-44.

Simons, Mandy-Judith Tonhauser-David Beaver-Craige Roberts 2010. What projects and why? In: SALT 20:309-27.

Simonyi, Zsigmond 1892. A magyar határozók II [The Hungarian adverbials, part 2]. Magyar Tudományos Akadémia, Budapest.

Surányi, Balázs 2004. The left periphery and Cyclic Spellout: The case of Hungarian. In: Adger et al. (2004, 49-73).

Szabolcsi, Anna 1994. The noun phrase. In: Kiefer-É. Kiss (1994, 179-274).

Szabolcsi, Anna 2002. Hungarian disjunctions and positive polarity. In: Kenesei-Siptár (2002, 217-39).

Szücs, Márta 2010. A hadd problémaköre [Problems concerning hadd]. In: LingDok 9 : 193-214.

Tchizmarova, Ivelina 2005. Hedging functions of the Bulgarian discourse marker xajde. In: Journal of Pragmatics $37: 1143-63$.

Thurmair, Maria 1989. Modalpartikeln und ihre Kombinationen. Niemeyer, Tübingen.

Truckenbrodt, Hubert 2006. On the semantic motivation of syntactic verb movement to C in German. In: Theoretical Linguistics 32 : 257-306.

Truckenbrodt, Hubert to appear. Selbständige Verb-Letzt Sätze. In: Hans AltmannJörg Meibauer-Markus Steinbach (eds): Satztypen des Deutschen. De Gruyter, Berlin.

Tóth, Enikő 2006. A semantic approach to mood choice in complement clauses with special reference to Hungarian. Doctoral dissertation, University of Debrecen.

Turi, Gergő 2009. Kötőmód a mai magyar nyelvben [The subjunctive in present-day Hungarian]. In: Argumentum 5:25-38.

Ürögdi, Barbara 2012. Operator movement in embedded clauses. Doctoral dissertation. ELTE, Budapest. http://www.nytud.hu/szakcsoport/urogdivedes/urogdidissz.pdf

Urmson, James O. 1952. Parenthetical verbs. In: Mind 61:480-96. 
Varga, Diána 2012a. A magyar felszólító mondatok szerkezete [The structure of Hungarian imperative sentences]. In: LingDok $11: 253-71$.

Varga, Diána 2012b. A mód, a modalitás és az imperatív operátor viszonya a magyar felszólító mondatokban [The relationship between mood, modality, and the imperative operator in Hungarian imperative sentences]. In: Andrea Parapatics (ed.): Félúton 7 [Halfway 7]. ELTE BTK Nyelvtudományi Doktori Iskola, Budapest. http://linguistics.elte.hu/studies/fuk/fuk11/Varga\%20Diana-KESZ.pdf

Varga, László 1982. Két szintaktikai pozícióról [On two syntactic positions]. In: Magyar Nyelv $78: 150-69$.

Varga, László 2002. Intonation and stress: Evidence from Hungarian. Palgrave Macmillan, New York.

Vaskó, Ildikó 2001. The communicative function of the Hungarian adverbial marker majd 'later on, some time'. In: Enikő Németh T.-Károly Bibok (eds): Pragmatics and the flexibility of word meaning (Current Research in the Semantics/Pragmatics Interface 8), 274-87. Elsevier, Amsterdam.

Weydt, Harald 1969. Abtönungspartikel. Gehlen, Bad Homburg.

Wilson, Deirdre-Dan Sperber 1988. Mood and the analysis of non-declarative sentences. In: Jonathan Dancy - Julius Moravcsik - Christopher Taylor (eds): Human agency, 77-101. Stanford University Press, Stanford CA.

Zwart, Jan-Wouter 1993. Dutch syntax. Doctoral dissertation, University of Groningen.

Zwicky, Arnold M. 1985. Clitics and particles. In: Language 61:283-305. 